\title{
Novel strategy to identify genetic risk factors for COPD severity: a genetic isolate
}

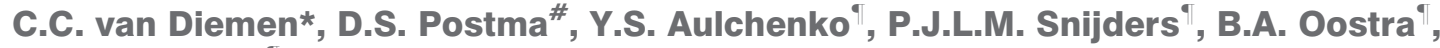 \\ C.M. van Duijn and H.M. Boezen*
}

ABSTRACT: Studies using genetic isolates with limited genetic variation may be useful in chronic obstructive pulmonary disease (COPD) genetics, but are thus far lacking. The associations between single nucleotide polymorphisms (SNPs) in candidate genes and lung function in COPD were studied in a genetic isolate.

In 91 subjects with Global Initiative for Chronic Obstructive Lung Disease (GOLD) stage $\geqslant 1$ COPD, who were members of an extended pedigree including 6,175 people from the Genetic Research in Isolated Populations study, 32 SNPs were analysed in 13 candidate genes: a disintegrin and metalloprotease domain 33 gene (ADAM33), transforming growth factor- $\beta 1$ gene (TGFB1), matrix metalloprotease-1 gene (MMP1), MMP2, MMP9, MMP12, tissue inhibitor of metalloprotease-1 gene (TIMP1), surfactant protein A1 gene (SFTPA1), SFTPA2, SFTPB, SFTPD, glutathione S-transferase P1 gene (GSTP1), and haem oxygenase 1 gene (HMOX1). Their relation to forced expiratory volume in $1 \mathrm{~s}$ (FEV 1 ), inspiratory vital capacity (IVC) and FEV $1 /$ IVC were studied using restricted maximum likelihood linear mixed modelling, accounting for pedigree structure. Significant associations were replicated in the general Vlagtwedde/Vlaardingen study.

Six SNPs in TGFB1, SFTPA1, SFTPA2 and SFTPD were significantly associated with FEV $1 /$ IVC in subjects with GOLD stage $\geqslant 1$ COPD. Two SNPs in TGFB1 (C to T substitution at nucleotide -509 and substitution of leucine 10 with proline (Leu10Pro)), Leu50Val in SFTPA1 and Ala160Thr in SFTPD showed evidence suggestive of association with FEV $1 /$ IVC in subjects with GOLD stage $\geqslant 2$ COPD. The TGFB1 associations were replicated in GOLD stage $\geqslant 2$ patients from the Vlagtwedde/ Vlaardingen population, with similar effect sizes.

It was shown that a genetic isolate can be used to determine the genetics of lung function, which can be replicated in COPD patients from an independent population.

KEYWORDS: Chronic obstructive pulmonary disease, genetically isolated population, lung function, single nucleotide polymorphism

hronic obstructive pulmonary disease (COPD) is the third leading cause of death worldwide, and is expected to increase in prevalence until 2030 [1, 2]. The disease has a large personal, societal, and economic impact. COPD is characterised by chronic airway inflammation, airway remodelling and airflow limitation that is not fully reversible. Since not all smokers develop COPD, genetic susceptibility must play a role in the development of this disease, in addition to environmental factors. The genetic determinants for COPD are difficult to study, since COPD is a disease that becomes clinically manifest only at later ages, when parents of COPD patients have already died and their children are probably too young to manifest airway obstruction. This limits the option of performing family-based genetic research. Moreover, published studies frequently use various definitions of disease status, which makes it difficult to compare their results. Therefore, it makes sense to choose a robust phenotype for definition of COPD, such as the level of lung function, which can be more easily compared between studies. Moreover, a low level of lung function is a predictor of mortality due to COPD [3-5].

Another complicating factor in studies on the genetics of COPD is that COPD is considered a complex genetic trait, i.e. multiple, possibly interacting, genetic and environmental factors are involved. Therefore, there are advantages to attempting to identify risk genes in populations that are relatively genetically and environmentally homogeneous, such as genetically isolated populations, in which genetic variation is reduced owing to the small number of founders
AFFILIATIONS

Depts of *Epidemiology and

\#Pulmonology, University Medical Center Groningen, University of Groningen, Groningen, and

"Epidemiology and Biostatistics, Erasmus Medical Center Rotterdam, Rotterdam, the Netherlands.

CORRESPONDENCE

H.M. Boezen

Dept of Epidemiology, E3.29

University Medical Center Groningen

P.0. Box 30.001

9700 RD Groningen

The Netherlands

E-mail: h.m.boezen@epi.umcg.nl

Received:

April 092008

Accepted after revision:

Aug 282009

First published online:

Sept 242009 
and drift [6]. However, these processes raise the question of whether findings can be extrapolated to the general population. Previous simulation studies suggest that this is the case for common variants with a frequency of $>1 \%$ [6], but no empirical evidence is available.

A candidate gene study was conducted for level of airflow limitation in patients with COPD who were ascertained as part of the Genetic Research in Isolated Populations (GRIP) study that is being conducted in a young genetically isolated population from the south-western part of the Netherlands. All patients were genotyped using 32 single nucleotide polymorphisms (SNPs) in 13 candidate genes for COPD, chosen based on their previously published association with either COPD, level of lung function or lung function decline, as reported in the general population. Extensive genealogical information was collected, resulting in an extremely large and complex pedigree of 6,175 members. Finally, 1,390 Caucasians from the general Dutch population were studied, including 351 patients with COPD, in order to establish whether or not the present findings could be replicated in the general population. In both studies, it was investigated whether the severity of the disease, as reflected by lung function reduction, is genetically influenced in established COPD.

\section{METHODS}

\section{Study populations}

The present study forms part of the GRIP programme [7, 8]. The GRIP programme is based in a recently genetically isolated population from the south-western part of the Netherlands, which was founded in the middle of the eighteenth century by $\sim 150$ individuals and was genetically isolated until the middle of the twentieth century. The population now includes $\sim 20,000$ inhabitants in eight adjacent communities. GRIP programme participants are generally related via multiple lines of descent and are inbred via multiple consanguineous loops $[9,10]$.

Subjects with general-practitioner-diagnosed COPD were invited to the research centre to undergo spirometry and complete a questionnaire [11]. Spirometry was performed by trained pulmonary research technicians using a pneumotachograph (Viasys, Houten, the Netherlands; formerly Jaeger spirometry system). Predicted values for forced expiratory volume in $1 \mathrm{~s}$ (FEV1) were calculated using adjusted QUANJER et al. [12] equations for Caucasian subjects. DNA was isolated from blood using Puregene ${ }^{\circledR}$ DNA Purification Kits (Gentra, Inc., Minneapolis, MN, USA). All participants gave written informed consent.

In order to verify the findings from the GRIP study in the general population, cross-sectional data from the generalpopulation-based Vlagtwedde/Vlaardingen cohort were used. Questionnaires, spirometric results and DNA were collected $[13,14]$. For this study, 351 subjects were selected, according to Global Initiative for Chronic Obstructive Lung Disease (GOLD) criteria, with GOLD stage $\geqslant 1$ COPD at the last 1989/1990 survey, of whom 167 had GOLD stage $\geqslant 2$ COPD [15].

\section{Genotyping}

SNPs in candidate genes for lung function and COPD, based on their previously published significant associations, were genotyped (table 1). The selected SNPs were either the most significant SNPs in previous studies, tagging SNPs for the gene, or SNPs with a known functional effect on gene expression or function. Genotyping was performed using Applied Biosystems TaqMan ${ }_{\circledast}$ SNP Genotyping Assays (Applied Biosystems, Nieuwerkerk aan de IJssel, the Netherlands). Sequences of primers and probes are available on request.

\section{Statistical analysis}

In order to analyse pedigree data, use was made of the measured genotype (MG) approach [33], which models quantitative traits as

$$
y_{i}=\mu+k g_{i}+\sum_{j} \beta_{j} c_{j i}+G_{i}+e_{i}
$$

where $y_{i}$ is the phenotype of the $i$ th individual, $g$ the vector of genotypes at the marker under study, $k$ the marker genotype effect, $c_{i j}$ the value of the $j$ th covariate or fixed effect for the individual $i, \beta_{j}$ an estimate of the $j$ th fixed effect or covariate and $G_{i}$ and $e_{i}$ random additive polygenic and residual effects, respectively. The random effects are assumed to follow multivariate normal distribution with a mean of zero. The variance for the polygenic effects is defined as $\Phi \sigma_{\mathrm{G}}{ }^{2}$, where $\Phi$ is the relationship matrix and $\sigma_{\mathrm{G}}{ }^{2}$ the additive genetic variance due to polygenes. For the residual random effects, the variance is defined as $I \sigma_{e}{ }^{2}$, where $I$ is the identity matrix and $\sigma_{e}{ }^{2}$ the residual variance.

Since the pedigree under analysis was very large, fast genomewide rapid association using mixed model and regression (GRAMMAR) approximation to the full MG approach was used [34]. The GRAMMAR consists of a fast though conservative test at the screening stage, followed up with full MG analysis of polymorphisms that pass the relaxed screening significance threshold $(\mathrm{p}<0.1)$. All analyses involving pedigree were performed using ASReml v2.0 [35], a package for linear mixed model analysis using restricted maximum likelihood. This is a joint venture between the biometrics programme of the New South Wales Department of Primary Industries (Orange, Australia) and the Biomathematics University of Rothamsted Research (Harpenden, UK). Statisticians in the UK and Australia have collaborated in its development.

Significant associations were tested using linear regression analyses in the Vlagtwedde/Vlaardingen population. All analyses were adjusted for age, height and sex.

\section{RESULTS}

\section{GRIP study population}

A total of 157 individuals who were diagnosed with COPD by their general practitioners were ascertained. Spirometric measures confirmed COPD in 91 subjects, i.e. subjects with GOLD stage $\geqslant 1$ COPD (defined by an FEV1/inspiratory vital capacity (IVC) of $<70 \%$ ) [15]. The rest of the subjects could not be defined as having COPD according to their spirometric results and were, therefore, excluded from the analyses. The familial relationship of these 91 subjects was determined in the larger GRIP study database. This resulted in a large extended pedigree structure of 6,175 members. The characteristics of the GRIP COPD population and the Vlagtwedde/Vlaardingen replication cohort are shown in table 2 . 
TABLE 1 Candidate genes and single nucleotide polymorphisms (SNPS) genotyped in the study population

\begin{tabular}{|c|c|c|c|c|c|}
\hline \multirow[t]{2}{*}{ Gene } & \multirow[t]{2}{*}{ Description of gene } & \multicolumn{2}{|c|}{ SNPs genotyped } & \multirow[t]{2}{*}{ Functional SNP } & \multirow[t]{2}{*}{ [Refs] } \\
\hline & & ID & Alternative name & & \\
\hline ADAM33 & $\begin{array}{l}\text { A disintegrin and metalloprotease domain 33: exact function } \\
\text { unknown; identified by genome-wide screen as susceptibility } \\
\text { gene for asthma. Associated with decline in FEV } 1 \text { and } \\
\text { development of COPD in the general population and severity of } \\
\text { inflammation in COPD patients. }\end{array}$ & $\begin{array}{c}\text { rs17548913 } \\
\text { rs17548907 } \\
\text { rs3918396 } \\
\text { rs528557 } \\
\text { rs597980 } \\
\text { rs2280091 } \\
\text { rs2280090 } \\
\text { rs2787094 }\end{array}$ & $\begin{array}{l}\text { ADAM33 F+1 } \\
\text { ADAM33 Q-1 } \\
\text { ADAM33 S1 } \\
\text { ADAM33 S2 } \\
\text { ADAM33 ST+5 } \\
\text { ADAM33 T1 } \\
\text { ADAM33 T2 } \\
\text { ADAM33 } 44\end{array}$ & & {$[13,16]$} \\
\hline TGFB1 & $\begin{array}{l}\text { TGF- } \beta 1 \text { : a chemotactic cytokine for fibroblasts, inducing synthesis } \\
\text { of matrix proteins and glycoproteins and inhibiting collagen } \\
\text { degradation by induction of protease inhibitors and reduction of } \\
\text { metalloproteases; TGF- } \beta 1 \text { levels are increased in COPD; SNPS } \\
\text { have been associated with COPD. }\end{array}$ & $\begin{array}{l}\text { rs1800469 } \\
\text { rs1982073 } \\
\text { rs6957 }\end{array}$ & $\begin{array}{l}\text { TGFB1 }-509 C>\text { T } \\
\text { TGFB1 Leu10Pro } \\
\text { TGFB1 3'UTR }\end{array}$ & $\begin{array}{l}\text { Increased TGF- } \beta 1 \\
\text { Increased TGF- } \beta 1\end{array}$ & {$[14,17-19]$} \\
\hline SFTPA2 & SP-A2: as for SP-A1, homologous gene. & $\begin{array}{l}\text { rs1059046 } \\
\text { rs17886395 } \\
\text { rs1965707 }\end{array}$ & $\begin{array}{l}\text { SPA2 Asn9Thr, } \\
\text { SPA2 Pro91Ala, } \\
\text { SPA2 Ser140Ser }\end{array}$ & & \\
\hline SFTPB & SP-B: hydrophobic component of pulmonary surfactant. & rs1130866 & SPB lle131Thr & Altered affinity & \\
\hline SFTPD & $\begin{array}{l}\text { SP-D: a C-type lectin present in pulmonary surfactant and several } \\
\text { other mucosal surfaces. It modulates innate immunity, allergic } \\
\text { response, expression of MMPs, alveolar wall remodelling, } \\
\text { emphysema, fibrosis and lipid and macrophage homeostasis. } \\
\text { Associated with COPD. }\end{array}$ & $\begin{array}{l}\text { rs721917 } \\
\text { rs2243639 }\end{array}$ & $\begin{array}{l}\text { SPD Met11Thr } \\
\text { SPD Thr160Ala }\end{array}$ & $\begin{array}{l}\text { Altered SP-D assembly, function } \\
\text { and levels }\end{array}$ & \\
\hline MMP9 & $\begin{array}{l}\text { MMP-9: a gelatinase B involved in tissue remodelling; smokers } \\
\text { with airway obstruction show higher MMP-9 expression than } \\
\text { smokers without COPD and nonsmokers. }\end{array}$ & $\begin{array}{l}\text { rs3918278 } \\
\text { rs6065912 } \\
\text { rs8113877 }\end{array}$ & $\begin{array}{l}\text { mmp9_rs3918278 } \\
\text { mmp9_rs6065912 } \\
\text { mmp9_rs8113877 }\end{array}$ & $\begin{array}{l}\text { Tagging } \\
\text { Tagging } \\
\text { Tagging }\end{array}$ & {$[24,27]$} \\
\hline MMP12 & $\begin{array}{l}\text { MMP-12: a human macrophage elastase involved in degradation } \\
\text { of extracellular matrix in lungs of patients with COPD. Associated } \\
\text { with lung function decline. }\end{array}$ & $\begin{array}{l}\text { rs2276109 } \\
\text { rs652438 }\end{array}$ & $\begin{array}{l}\text { MMP12 -82A>G } \\
\text { MMP12 Asn357Ser }\end{array}$ & $\begin{array}{l}\text { AP-1 transcription factor binding } \\
\text { site, increased MMP-12 }\end{array}$ & [24] \\
\hline TIMP1 & $\begin{array}{l}\text { Tissue inhibitor of metalloprotease-1: inhibitor of several MMPs, } \\
\text { including MMP-1, MMP-9 and MMP-12. X-chromosomal. } \\
\text { Associated with asthma. }\end{array}$ & $\begin{array}{l}\text { rs11551797 } \\
\text { rs4898 }\end{array}$ & $\begin{array}{l}\text { timp1 lle158lle } \\
\text { timp1 Phe124Phe }\end{array}$ & & [28] \\
\hline HMOX1 & $\begin{array}{l}\text { Haem oxygenase 1: role in oxidant-antioxidant balance in the lung. } \\
\text { Genetic variation associated with COPD. }\end{array}$ & rs2071747 & HO1 Asp7His & & [29] \\
\hline GSTP1 & $\begin{array}{l}\text { Glutathione S-transferase P1: role in oxidant-antioxidant } \\
\text { balance in the lung. Associated with COPD. }\end{array}$ & $\begin{array}{l}\text { rs1695 } \\
\text { rs1138272 }\end{array}$ & $\begin{array}{l}\text { gstp1 lle105Val } \\
\text { gstp1 Ala114Val }\end{array}$ & Increased enzyme activity & [30-32] \\
\hline
\end{tabular}

ID: identifier; ADAM33: a disintegrin and metalloprotease domain 33 gene; TGFB1: transforming growth factor- $\beta 1$ gene; SFTPA1: surfactant protein A1 gene; MMP1: matrix metalloprotease-1 gene; TIMP1: tissue inhibitor of metalloprotease-1 gene; HMOX1: haem oxygenase 1 gene; GSTP1: glutathione S-transferase P1 gene; FEV1: forced expiratory volume in $1 \mathrm{~s}$; COPD: chronic obstructive pulmonary disease; TGF- $\beta$ : transforming growth factor- $\beta$; SP: surfactant protein; MMP: matrix metalloprotease; ADAM: a disintegrin and metalloprotease; -509C>T: cytosine (C) to thymidine (T) substitution at nucleotide -509; G: guanine; A: adenine; Leu10Pro: substitution of leucine 10 with proline; Val: valine; Ala: alanine; Arg: arginine; Trp: tryptophan; Asn: asparagine; Thr: threonine; Ser: serine; lle: isoleucine; Met: methionine; Phe: phenylalanine; Asp: aspartic acid; His: histidine; UTR: untranslated region; HO: haem oxygenase; Ets: erythroblastosis virus E26 oncogene homologue; AP-1: activator protein-1. 


\begin{tabular}{|c|c|c|c|c|c|c|}
\hline \multirow[t]{3}{*}{ TABLE 2} & of the Genetic $\mathrm{P}$ & rch in Isolated & ulations ( & P) and Vlagtwe & /laardingen (V & a) study \\
\hline & \multicolumn{3}{|c|}{ Total population } & \multicolumn{3}{|c|}{ FEV $_{1}<80 \%$ pred } \\
\hline & GRIP & Vla/Vla & p-value ${ }^{\#}$ & GRIP & Vla/Vla & p-value ${ }^{\#}$ \\
\hline Subjects $n$ & 91 & 351 & & 67 & 167 & \\
\hline \multicolumn{7}{|l|}{ Smoking \% } \\
\hline Never-smoker & 3.4 & 18.8 & 0.001 & 3.1 & 16.2 & 0.026 \\
\hline Ex-smoker & 38.6 & 35.9 & & 38.5 & 33.5 & \\
\hline Current smoker & 58.0 & 45.3 & & 58.4 & 50.3 & \\
\hline Smoking history pack-yrs & $34.8(0-120)$ & $21.4(0-262)$ & 0.001 & $39.0(0-120)$ & $26.0(0-262)$ & 0.015 \\
\hline Chronic phlegm \% & 50.5 & 10.5 & $<0.001$ & 51.5 & 15.0 & $<0.001$ \\
\hline
\end{tabular}

\section{Association of genes with lung function parameters in GRIP, and replication in Vlagtwedde/Vlaardingen}

The effects of SNPs in the studied genes on percentage predicted FEV1, IVC and FEV1/IVC were first analysed in the 91 subjects with GOLD stage $\geqslant 1$ COPD. None of the SNPs were associated with percentage predicted FEV1 or IVC. Six $\mathrm{SNPs}$ in the transforming growth factor- $\beta 1$ gene (TGFB1), surfactant protein A1 gene (SFTPA1), SFTPA2 and SFTPD were significantly associated with FEV1/IVC (table 3). None of these associations were replicated in subjects from the Vlagtwedde/Vlaardingen cohort with GOLD stage $\geqslant 1$ COPD (data not shown).

In addition, the effects of SNPs in the studied genes were analysed using a more stringent definition of COPD, namely GOLD stage $\geqslant=2$ (defined as FEV1/IVC of $<70 \%$ and FEV1 of $<80 \%$ pred). This resulted in 67 cases in the GRIP population. In these subjects, two SNPs in TGFB1 (cytosine to thymidine substitution at nucleotide $-509(-509 \mathrm{C}>\mathrm{T})$ and substitution of leucine 10 with proline (Leu10Pro)), Leu50Val in SFTPA1 and Ala160Thr in SFTPD showed evidence suggestive of association with FEV1/IVC $(\mathrm{p}<0.10)$ (table 3). The TGFB1 -509C $>$ T and Leu10Pro associations were replicated in GOLD stage $\geqslant 2$ subjects from the Vlagtwedde/Vlaardingen population $(n=167)$, with similar effect sizes (see table 3$)$.

\section{DISCUSSION}

The present study is the first to use a genetically isolated population to analyse genetic effects on level of lung function in COPD. Interestingly, significant effects of SNPs in COPD candidate genes were found on severity of COPD, assessed by lung function in subjects with COPD, even though the present study population was small. The present results show that levels of FEV1/IVC, measures of airway obstruction, are genetically influenced in established COPD. This means that, even within patients with phenotypic COPD, genotypes can be identified that are associated with severity of disease. This is of clinical importance since low lung function has been shown to predict mortality in COPD, not only in the general population but also within COPD patients [3-5].

The TGFB1 SNPs that were associated with FEV1/IVC in the present populations have previously been associated with development of COPD or with lower FEV1 and FEV1/VC in several [17-19], but not all previous studies [14, 36, 37]. The present results (in both the genetically isolated and general population) thus confirm the former studies that implicate a role of TGFB1 in the severity of airflow limitation. The SFTPA1 and SFTPD SNPs have been associated with COPD previously $[20,38]$. It is now shown for the first time that these SNPs may also play a role in severity of COPD. This is plausible since surfactant proteins decrease surface tension at the air-liquid interface and, therefore, reduce the tendency of alveoli to collapse during expiration. The latter contributes to the severity of airway obstruction, as measured by FEV1/IVC.

No significant associations of a disintegrin and metalloprotease domain 33 gene (ADAM33), matrix metalloprotease-1 gene (MMP1), MMP2, MMP9, MMP12, tissue inhibitor of metalloprotease-1 gene (TIMP1), SFTPB, glutathione S-transferase P1 gene (GSTP1) and haem oxygenase 1 gene (HMOX1) with level of lung function were found in COPD patients. This does not, however, imply that these genes do not play any role whatsoever in COPD. To date, no studies have analysed genetic effects on the severity of airway obstruction within patients with established COPD. The present study shows that SNPs in TGFB1, SFTPA1 and SFTPD may be important in progression of COPD, whereas the SNPs in the other genes, i.e. ADAM33, MMP1, MMP2, MMP9, MMP12, TIMP1, GSTP1 and HMOX1, may simply constitute SNPs that are important in the development of COPD. 


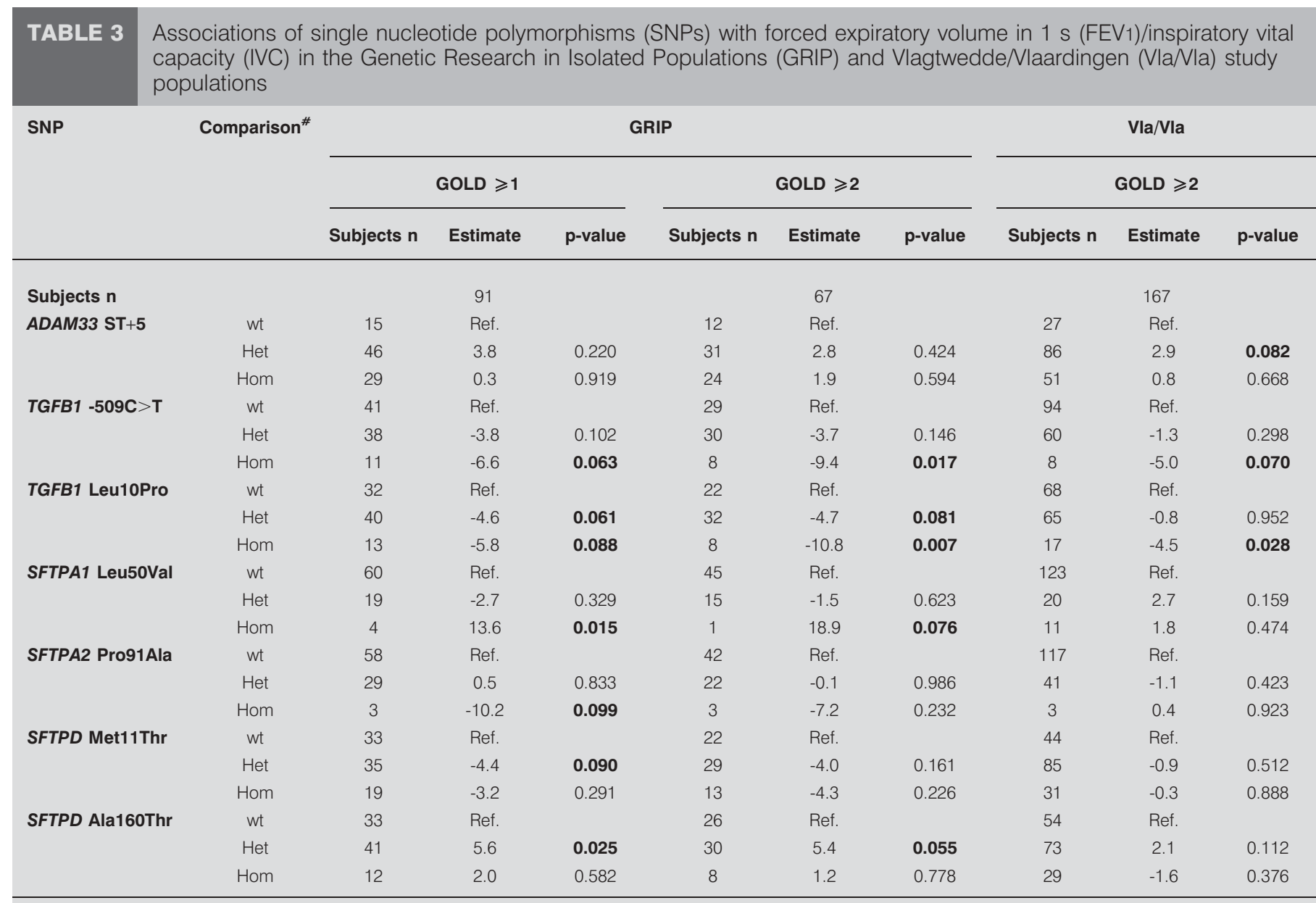

A general model of inheritance was used, in which the mutant genotypes were compared to the wild-type (Wt). GOLD: Global Initiative for Chronic Obstructive Lung Disease; ADAM33: a disintegrin and metalloprotease domain 33 gene; TGFB1: transforming growth factor- $\beta 1$ gene; $-509 C>T$ : cytosine to thymidine substitution at nucleotide -509; Leu10Pro: substitution of leucine 10 with proline; SFTPA1: surfactant protein A1 gene; Val: valine; Ala: alanine; Met: methionine; Thr: threonine; Het: heterogzygous; Hom: homozygous; Ref.: reference genotype. \#: versus wild-type.

One important advantage of testing genes in a genetically isolated population is that it provides an opportunity of finding genes associated with disease in a relatively small sample size due to increased homogeneity of the population, as recently demonstrated for multiple sclerosis [39]. Thus, for a lower cost and effort, many genes can be tested regarding their significance in contributing to disease severity, which can subsequently be replicated in a larger sample of the general population. The most important requirement for such studies is that the genetic isolate is representative of the general population or disease-specific study populations. This is indeed the case since it was shown that, in selected subjects with COPD from the general population, the associations found in the young genetic isolate can be replicated in a substantial part. Thus it is possible to translate findings in a genetic isolate to the general population, but correct and comparable phenotyping of the study populations remains crucial to replicate associations between populations.

It was not possible to replicate the results of any of the SNPs in subjects with GOLD stage $\geqslant 1$ COPD from the Vlagtwedde/ Vlaardingen population. On closer investigation, it appeared that the GRIP patients with GOLD stage $\geqslant 1$ COPD had more severe COPD, i.e. lower lung function and more symptoms, than COPD patients of similar disease stage in the Vlagtwedde/Vlaardingen population. A more strict definition of COPD (GOLD stage $\geqslant=2$ ) in the Vlagtwedde/Vlaardingen and GRIP populations gave a phenotypically better comparison. Indeed, when analysing subjects with GOLD stage $\geqslant 2$ COPD from the Vlagtwedde/Vlaardingen population, the TGFB1 SNPs $-509 \mathrm{C}>\mathrm{T}$ and Leu10Pro were significantly associated with FEV1/IVC, as they were in the GRIP GOLD stage $\geqslant 2$ COPD patients.

Since the percentage of subjects with, amongst others chronic cough, was different in both cohorts, the analyses were repeated using straightforward linear regression models with chronic cough in the model to check for stability of the effect estimates. Analyses on FEV1/IVC in the GRIP GOLD stage $\geqslant 2$ population, taking, for example, chronic cough into account, resulted in similar regression estimates for the SNPs in TGFB1 and SFTPA1, but with smaller p-values and slightly higher explained variances, whereas the suggestive associations of the other SNPs disappeared. Additional adjustment for chronic 


\begin{tabular}{|c|c|c|c|c|}
\hline TABLE 4 & \multicolumn{4}{|c|}{$\begin{array}{l}\text { Genotype frequencies of significant single } \\
\text { nucleotide polymorphisms in the Genetic } \\
\text { Research in Isolated Populations (GRIP) } \\
\text { compared to the Vlagtwedde/Vlaardingen (Vla/ } \\
\text { Vla) Global Initiative for Chronic Obstructive Lung } \\
\text { Disease } \geqslant 2 \text { population }\end{array}$} \\
\hline Genotype & & GRIP & Vla/Vla & p-value \\
\hline \multirow{2}{*}{\multicolumn{5}{|c|}{$\begin{array}{l}\text { Subjects } \mathrm{n} \\
\text { ADAM33 } \mathrm{ST}+5\end{array}$}} \\
\hline & & & & \\
\hline \multicolumn{2}{|l|}{ AA } & 12 (17.9) & 27 (16.5) & 0.690 \\
\hline \multicolumn{2}{|l|}{$A G$} & $31(46.3)$ & $86(52.4)$ & \\
\hline \multicolumn{2}{|l|}{$\mathrm{GG}$} & $24(35.8)$ & $51(31.1)$ & \\
\hline \multicolumn{5}{|c|}{ TGFB1 $-509 C>T$} \\
\hline \multicolumn{2}{|l|}{$G G$} & 29 (43.3) & $94(58.0)$ & 0.051 \\
\hline \multicolumn{2}{|l|}{ GA } & $30(44.8)$ & $60(37.0)$ & \\
\hline \multicolumn{2}{|l|}{ AA } & $8(11.9)$ & $8(4.9)$ & \\
\hline \multicolumn{5}{|c|}{ TGFB1 Leu10Pro } \\
\hline \multicolumn{2}{|l|}{$A A$} & $22(34.9)$ & 68 (45.3) & 0.368 \\
\hline \multicolumn{2}{|l|}{$A G$} & $33(52.4)$ & 65 (43.3) & \\
\hline \multicolumn{2}{|l|}{ GG } & $8(12.7)$ & 17 (11.3) & \\
\hline \multicolumn{5}{|c|}{ SFTPA1 Leu50Val } \\
\hline \multicolumn{2}{|l|}{$G G$} & 45 (73.8) & $123(79.9)$ & 0.045 \\
\hline \multicolumn{2}{|l|}{$\mathrm{GC}$} & $15(24.6)$ & $20(13.0)$ & \\
\hline \multicolumn{2}{|l|}{$\mathrm{CC}$} & $1(3.1)$ & $11(7.1)$ & \\
\hline \multicolumn{5}{|c|}{ SFTPA2 Pro91Ala } \\
\hline \multicolumn{2}{|l|}{$\mathrm{GG}$} & 42 (62.7) & $117(72.7)$ & 0.242 \\
\hline \multicolumn{2}{|l|}{ GC } & 22 (32.8) & $41(25.5)$ & \\
\hline \multicolumn{2}{|l|}{$\mathrm{CC}$} & $3(4.5)$ & $3(1.9)$ & \\
\hline \multicolumn{5}{|c|}{ SFTPD Met11Thr } \\
\hline \multicolumn{2}{|l|}{ TT } & $22(34.4)$ & $44(27.5)$ & 0.522 \\
\hline \multicolumn{2}{|l|}{ TC } & $29(45.3)$ & $8553.1)$ & \\
\hline \multicolumn{2}{|l|}{ CC } & $13(20.3)$ & $31(19.4)$ & \\
\hline \multicolumn{5}{|c|}{ SFTPD Ala160Thr } \\
\hline \multicolumn{2}{|c|}{ AA } & $26(40.6)$ & 54 (34.6) & 0.484 \\
\hline \multicolumn{2}{|l|}{$A G$} & $30(46.9)$ & 73 (46.8) & \\
\hline \multicolumn{2}{|l|}{ GG } & $8(12.5)$ & $29(18.6)$ & \\
\hline
\end{tabular}

Data are presented as $n(\%)$ unless otherwise indicated. ADAM33: a disintegrin and metalloprotease domain 33 gene; $A$ : adenine; G: guanine; TGFB1 transforming growth factor- $\beta 1$ gene; $-509 \mathrm{C}>\mathrm{T}$ : cytosine $(\mathrm{C})$ to thymidine $(\mathrm{T})$ substitution at nucleotide -509; Leu10Pro: substitution of leucine 10 with proline; SFTPA1: surfactant protein A1 gene; Val: valine; Ala: alanine; Met: methionine; Thr: threonine.

cough in the Vlagtwedde/Vlaardingen GOLD stage $\geqslant 2$ population resulted in similar significant regression estimates for the SNPs in TGFB1 with FEV1/IVC. Therefore, the effect estimates appear to be stable within both GOLD stage $\geqslant 2$ groups, irrespective of differences in characteristics between the GRIP and Vlagtwedde/Vlaardingen GOLD stage $\geqslant 2$ populations.

Several explanations may exist for the lack of replication for SFTPA1 and SFTPD (Met11Thr) SNP FEV1/IVC results in the Vlagtwedde/Vlaardingen GOLD stage $\geqslant 2$ population. First, the original GRIP findings on these genes could be falsely positive. Indeed, multiple (though correlated) outcomes and SNPs were studied in GRIP. Another, more biological, explanation for the lack of replication may be that the prevalence of certain alleles in genetically isolated populations differs from that in a general population as a result of genetic drift and founder effects. Indeed, the genotype frequencies for the SFTPA1 Leu50Val SNP were significantly different between the two populations, but not for the other SNPs (table 4). A third explanation may be that differences in characteristics exist between the study populations. The GRIP population had more severe COPD and was slightly older than the Vlagtwedde/Vlaardingen COPD population.

In addition, differences in environment may affect the lack of replication of the surfactant protein gene data. The genetically isolated population shares the same environment, similar socioeconomic status and the same general practitioners. The possibility cannot be ruled out that the COPD patients in the GRIP population exhibited a higher prevalence of chronic bronchitis and airway disease, whereas the airway obstruction in the Vlagtwedde/Vlaardingen population may have been caused by emphysema [40-42]. Further research is needed in order to separately assess these phenomena, since computed tomographic scans are necessary, which were not available for any of the present patients.

In conclusion, the present study provides two important messages. First, significant effects of SNPs were found on the severity of COPD, i.e. level of lung function in patients with established COPD, in a relatively small genetically isolated population with a large pedigree structure. Secondly, two of these associations were replicated in COPD patients selected from the general population on the condition that they were phenotypically similar. These findings are important since more severe airway obstruction is associated with progression and mortality of COPD. Future studies using this genetic isolate should focus on progression of COPD, since this population seems to be highly suitable for determining genetic risk factors for severity of airway obstruction in established COPD that can be translated to the general population.

\section{SUPPORT STATEMENT}

The Dutch Asthma Foundation (Leusden, the Netherlands) funded the collection of lung function data (NAF 3.4.04.041). C.C. van Diemen is assigned through the Dutch Asthma Foundation (NAF3.2.02.51). The Genetic Research in Isolated Populations programme is supported by grants from the Netherlands Organisation for Scientific Research (The Hague, the Netherlands; Pioneer grant to C.M. van Duijn) and the Center for Medical Systems Biology (Leiden, the Netherlands).

\section{STATEMENT OF INTEREST}

None declared.

\section{ACKNOWLEDGEMENTS}

We thank L. Testers (Erasmus Medical Center Rotterdam, Rotterdam, the Netherlands) for help in fieldwork logistics and DNA collection, and M. Farenhorst, T. van Hoogdalem, J. Post, A. Verbokkem and K. Vink-Klooster (all University Medical Center Groningen, University of Groningen, Groningen, the Netherlands) for collecting the lung function data. We would like to thank P. Veraart, H. Kornman and E. Boeren (all Erasmus Medical Center Rotterdam) for their contribution to the genealogical research. We would like to thank all of the participants in the Genetic Research in Isolated Populations (GRIP) study for their cooperation, as well as the general practitioners that made this work possible. All of the research assistants of the GRIP study are acknowledged for their help in data collection. 


\section{REFERENCES}

1 World Health Organization. The World Health Report 2002. www. who.int/whr/2002/en/index.html Date last updated: October 2002. Date last accessed: June 2, 2008.

2 Murtagh E, Heaney L, Gingles J, et al. The prevalence of obstructive lung disease in a general population sample: the NICECOPD study. Eur J Epidemiol 2005; 20: 443-453.

3 Ekberg-Aronsson M, Pehrsson K, Nilsson JA, et al. Mortality in GOLD stages of COPD and its dependence on symptoms of chronic bronchitis. Respir Res 2005; 6: 98.

4 Hospers JJ, Postma DS, Rijcken B, et al. Histamine airway hyperresponsiveness and mortality from chronic obstructive pulmonary disease: a cohort study. Lancet 2000; 356: 1313-1317.

5 Sin DD, Wu L, Man SF. The relationship between reduced lung function and cardiovascular mortality: a population-based study and a systematic review of the literature. Chest 2005; 127: 1952-1959.

6 Pardo LM, Mackay I, Oostra B, et al. The effect of genetic drift in a young genetically isolated population. Ann Hum Genet 2005; 69: 288-295.

7 Aulchenko YS, Heutink P, Mackay I, et al. Linkage disequilibrium in young genetically isolated Dutch population. Eur J Hum Genet 2004; 12: 527-534

8 Njajou OT, Alizadeh BZ, Aulchenko Y, et al. Heritability of serum iron, ferritin and transferrin saturation in a genetically isolated population, the Erasmus Rucphen Family (ERF) Study. Hum Hered 2006; 61: 222-228.

9 Liu F, Elefante S, van Duijn CM, et al. Ignoring distant genealogic loops leads to false-positives in homozygosity mapping. Ann Hum Genet 2006; 70: 965-970.

10 Liu F, Arias-Vásquez A, Sleegers K, et al. A genomewide screen for late-onset Alzheimer disease in a genetically isolated Dutch population. Am J Hum Genet 2007; 81: 17-31.

11 Boezen HM, Vonk JM, van Aalderen WM, et al. Perinatal predictors of respiratory symptoms and lung function at a young adult age. Eur Respir J 2002; 20: 383-390.

12 Quanjer PH, Tammeling GJ, Cotes JE, et al. Lung volumes and forced ventilatory flows. Eur Respir J 1993; 6: Suppl. 16, 5-40.

13 van Diemen CC, Postma DS, Vonk JM, et al. A disintegrin and metalloprotease 33 polymorphisms and lung function decline in the general population. Am J Respir Crit Care Med 2005; 172: 329-333.

14 van Diemen CC, Postma DS, Vonk JM, et al. Decorin and TGF- $\beta 1$ polymorphisms and development of COPD in a general population. Respir Res 2006; 7: 89.

15 Global Initiative for Chronic Obstructive Lung Disease. Global Strategy for the Diagnosis, Management and Prevention of Chronic Obstructive Pulmonary Disease (updated 2006). www. goldcopd.com/Guidelineitem.. spp $11=2 \& 12=1 \&$ intld $=996$ Date last updated: 2007. Date last accessed: June 2008.

16 Gosman MM, Boezen HM, van Diemen CC, et al. A disintegrin and metalloprotease 33 and chronic obstructive pulmonary disease pathophysiology. Thorax 2007; 62: 242-247.

17 Celedon JC, Lange C, Raby BA, et al. The transforming growth factor- $\beta 1$ (TGFB1) gene is associated with chronic obstructive pulmonary disease (COPD). Hum Mol Genet 2004; 13: 1649-1656.

18 Su ZG, Wen FQ, Feng YL, et al. Transforming growth factor- $\beta 1$ gene polymorphisms associated with chronic obstructive pulmonary disease in Chinese population. Acta Pharmacol Sin 2005; 26: 714-720.

$19 \mathrm{Wu}$ L, Chau J, Young RP, et al. Transforming growth factor- $\beta 1$ genotype and susceptibility to chronic obstructive pulmonary disease. Thorax 2004; 59: 126-129.

20 Guo X, Lin HM, Lin Z, et al. Surfactant protein gene A, B, and D marker alleles in chronic obstructive pulmonary disease of a Mexican population. Eur Respir J 2001; 18: 482-490.

21 Heidinger $\mathrm{K}$, Konig IR, Bohnert A, et al. Polymorphisms in the human surfactant protein-D (SFTPD) gene: strong evidence that serum levels of surfactant protein-D (SP-D) are genetically influenced. Immunogenetics 2005; 57: 1-7.

22 Hersh CP, DeMeo DL, Lazarus R, et al. Genetic association analysis of functional impairment in chronic obstructive pulmonary disease. Am J Respir Crit Care Med 2006; 173: 977-984.

23 Leth-Larsen R, Garred $\mathrm{P}$, Jensenius $\mathrm{H}$, et al. A common polymorphism in the SFTPD gene influences assembly, function, and concentration of surfactant protein D. J Immunol 2005; 174 1532-1538.

24 Joos L, He JQ, Shepherdson MB, et al. The role of matrix metalloproteinase polymorphisms in the rate of decline in lung function. Hum Mol Genet 2002; 11: 569-576.

25 Rutter JL, Mitchell TI, Buttice G, et al. A single nucleotide polymorphism in the matrix metalloproteinase- 1 promoter creates an Ets binding site and augments transcription. Cancer Res 1998; 58: 5321-5325.

26 Price SJ, Greaves DR, Watkins H. Identification of novel, functional genetic variants in the human matrix metalloproteinase-2 gene: role of Sp1 in allele-specific transcriptional regulation. J Biol Chem 2001; 276: 7549-7558.

27 Ito I, Nagai S, Handa T, et al. Matrix metalloproteinase-9 promoter polymorphism associated with upper lung dominant emphysema. Am J Respir Crit Care Med 2005; 172: 1378-1382.

28 Lose F, Thompson PJ, Duffy D, et al. A novel tissue inhibitor of metalloproteinase-1 (TIMP-1) polymorphism associated with asthma in Australian women. Thorax 2005; 60: 623-628.

29 Siedlinski M, van Diemen CC, Postma DS, et al. Heme oxygenase 1 variations and lung function decline in smokers: proof of replication. J Med Genet 2008; 45: 400.

30 Ishii T, Matsuse T, Teramoto S, et al. Glutathione S-transferase P1 (GSTP1) polymorphism in patients with chronic obstructive pulmonary disease. Thorax 1999; 54: 693-696.

31 Sundberg K, Johansson AS, Stenberg G, et al. Differences in the catalytic efficiencies of allelic variants of glutathione transferase P1-1 towards carcinogenic diol epoxides of polycyclic aromatic hydrocarbons. Carcinogenesis 1998; 19: 433-436.

32 Vibhuti A, Arif E, Deepak D, et al. Genetic polymorphisms of GSTP1 and $m E P H X$ correlate with oxidative stress markers and lung function in COPD. Biochem Biophys Res Commun 2007; 359: 136-142.

33 Boerwinkle E, Chakraborty R, Sing CF. The use of measured genotype information in the analysis of quantitative phenotypes in man. I. Models and analytical methods. Ann Hum Genet 1986; 50: 181-194.

34 Aulchenko YS, de Koning DJ, Haley C. Genomewide rapid association using mixed model and regression: a fast and simple method for genomewide pedigree-based quantitative trait loci association analysis. Genetics 2007; 177: 577-585.

35 Gilmour R., Gogel BJ., Cullis BR., Welham SJ., Thompson R. ASReml User Guide Release 1.0. Hemel Hempstead, VSN International, 2002.

36 Ogawa E, Ruan J, Connett JE, et al. Transforming growth factor- $\beta 1$ polymorphisms, airway responsiveness and lung function decline in smokers. Respir Med 2007; 101: 938-943.

37 Yoon HI, Silverman EK, Lee HW, et al. Lack of association between COPD and transforming growth factor- $\beta 1$ (TGFB1) genetic polymorphisms in Koreans. Int J Tuberc Lung Dis 2006; 10: 504-509.

38 van Diemen CC, Postma DS, Vonk JM, et al. Polymorphisms in surfactant proteins and FEV1 decline and development of COPD in the general population. Eur Respir J 2006; 28: Suppl. 50, 143s-144s.

39 Aulchenko YS, Hoppenbrouwers IA, Ramagopalan SV, et al. Genetic variation in the KIF1B locus influences susceptibility to multiple sclerosis. Nat Genet 2008; 40: 1402-1403.

40 DeMeo DL, Hersh CP, Hoffman EA, et al. Genetic determinants of emphysema distribution in the National Emphysema Treatment Trial. Am J Respir Crit Care Med 2007; 176: 42-48. 
41 Martinez FJ, Foster G, Curtis JL, et al. Predictors of mortality in patients with emphysema and severe airflow obstruction. Am J Respir Crit Care Med 2006; 173: 1326-1334.
42 Martinez FJ, Curtis JL, Sciurba F, et al. Gender differences in severe pulmonary emphysema. Am J Respir Crit Care Med 2007; 176: 234-252. 